\title{
Humanização e Alimentação em Instituições de Longa Permanência para Idosos
}

\author{
Escaldelai, Fernanda Martins Dias; Freita, Angélica Marques de Pina; Corrêa, \\ Amanda Caroline Cardoso
}

Faculdade de Saúde Pública - Universidade de São Paulo — fenanda2@yahoo.com.br

\begin{abstract}
INTRODUÇÃO As instituições de longa permanência para idosos (ILPI) são instituições governamentais ou não governamentais, de caráter residencial para domicílio coletivo de pessoas a partir dos 60 anos, com ou sem suporte familiar. Caracteriza-se como espaço de viver dos idosos e necessidades básicas, como saúde e alimentação, devem ser atendidas de forma humanizada. a atenção humanizada consiste em ofertar atendimento de qualidade, com acolhimento e fomento da autonomia dos sujeitos envolvidos. OBJETIVO Identificar os aspectos de humanização relacionados à alimentação dos usuários de duas ILPI da cidade de São Paulo. MÉTODO Pesquisa qualitativa, de caráter exploratório, baseada na política de humanização. Foram realizadas entrevistas com nutricionistas de duas ILPI, além de observação dos seus serviços de alimentação. As entrevistas foram baseadas em um questionário semiestruturado, realizadas com auxílio de gravador e posteriormente transcritas para análise. RESULTADOS Foram identificados aspectos de humanização, principalmente, acolhimento por parte dos profissionais envolvidos e autonomia dos usuários, conforme as regras das ILPI. o acolhimento foi identificado por meio da escuta das solicitações dos idosos em relação ao cardápio, com inclusão de preparações conforme suas preferências, hábitos e necessidades quanto à composição e consistência dos alimentos. a autonomia dos idosos pôde ser identificada em diferentes situações: no momento das refeições, na participação voluntária em atividades domésticas, desde que não envolvam riscos a sua saúde e segurança, na participação voluntária em atividades sócio-recreativas (festa para os aniversariantes do mês, saída em grupos para restaurantes comerciais) e na livre saída dos idosos para compra de alimentos com recursos próprios. CONSIDERAÇÕES FINAIS As ações e atividades relacionadas à alimentação permitem, além da nutrição, a ocupação do tempo, a socialização entre os idosos e sua integração à comunidade. em geral, os relatos permitiram identificar que há participação ativa dos idosos nas decisões relacionadas à sua alimentação, conforme os recursos financeiros de cada ILPI. Essa realidade com aspectos de humanização têm grande importância e deve ser incentivada, pois as ILPI são os locais de residência desses idosos.
\end{abstract}

Escaldelai, Fernanda Martins Dias; Freita, Angélica Marques de Pina; Corrêa, Amanda Caroline Cardoso. Humanização e Alimentação em Instituições de Longa Permanência para Idosos. In: Anais do Congresso Internacional de Humanidades \& Humanização em Saúde [= Blucher Medical Proceedings, num.2, vol.1]. São Paulo: Editora Blucher, 2014. ISSN 2357-7282

DOI 10.5151/medpro-cihhs-10659 